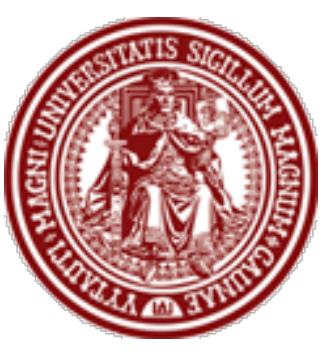

sciendo

\section{BALTIC JOURNAL OF LAW \& POLITICS}

A Journal of Vytautas Magnus University

VOLUME 13, NUMBER 1 (2020)

ISSN 2029-0454

Cit.: Baltic Journal of Law \& Politics 13:1 (2020): 1-23

https://content.sciendo.com/view/journals/bjlp/bjlp-

overview.xml

DOI: $10.2478 / \mathrm{bjlp}-2020-0001$

\title{
HERCULES IN THE COLOMBIAN CONSTITUTIONAL COURT
}

\section{Iván Garzón Vallejo}

Associate Professor

Universidad de La Sabana, Faculty of Law and Political Sciences (Colombia)

\section{Contact information}

Address: Campus del Puente del Común, Km. 7, Autopista Norte de Bogotá, Chía, Cundinamarca, Colombia

Phone: +57 3213137971

E-mail address: ivan.garzon1@unisabana.edu.co

\section{Cristian Rojas González}

Assistant Professor

Universidad de La Sabana, Faculty of Law and Political Sciences (Colombia)

Contact information

Address: Campus del Puente del Común, Km. 7, Autopista Norte de Bogotá, Chía, Cundinamarca, Colombia

Phone: +573577772

E-mail address: cristian.rojas@unisabana.edu.co

Received: October 21, 2019; reviews: 2; accepted: July 6, 2020.

\section{ABSTRACT}

This paper explores how the Colombian Constitutional Court has used the legal and political philosophy of Ronald Dworkin to show that the use of the concepts of rights as trump cards, individual autonomy, and state neutrality, have configured the reception of egalitarian liberalism. This conclusion is reached by means of an analysis of the meaning and use of these concepts in certain judicial decisions and of personal interviews with certain head justices and law clerks of said Court, which also made it possible to frame this question within the larger issue of the relationship of philosophy to the decisions of the judges. 


\section{KEYWORDS}

Ronald Dworkin, Colombian Constitutional Court, liberalism, rights, egalitarian 
We might therefore do well to consider how a philosophical judge might develop, in appropriate cases, theories of what legislative purpose and legal principles require [...] I have invented, for this purpose, a lawyer of superhuman skill, learning, patience and acumen, whom I shall call Hercules.

(Ronald Dworkin, Taking Rights Seriously, p. 105)

\section{INTRODUCTION}

The relationship between political philosophy and law has grown closer in recent decades. As Michael Walzer had already noted at the beginning of the eighties, "the revival of political philosophy has had its most dramatic impact in schools of law and for a reason that is not difficult to make out. In a settled democracy, with no revolution in prospect, judges are the most likely instruments of philosophical reformation". ${ }^{1}$ In addition, the constitutional courts constitute an area of privileged intersection between the work of judges and philosophers. Indeed, the constitutional courts have represented an important content source for political philosophy in recent decades; but at the same time they raise a serious problem since "the tension between judicial review and democracy directly parallels the tension between philosophy and democracy."2

This close and problematic relationship justifies some examination of the role of philosophy in the jurisprudence of one of the most activist constitutional courts in the world. Since the Colombian Constitutional Court (henceforth CCC) is widely recognized for its liberal and progressive decisions ${ }^{3}$, it is not particularly surprising that some decisions have been theoretically based on Ronald Dworkin, one of the main representatives of egalitarian liberalism.

Certainly, Dworkin is not the only philosopher of law that CCC has quoted, but according to the opinion of some judges interviewed, he is one of the most influential. Moreover, between 1994 and 2020 the CCC cited Ronald Dworkin in 21 decisions, which is not statistically significant, but it is enough for undertaking a theoretical analysis. In this sense, the goal of the article is to propose a scheme of analysis that could be applied to other constitutional courts.

\footnotetext{
1 Michael Walzer, Thinking Politically: Essays in Political Theory (New Haven: Yale University Press, 2007), 9.

${ }^{2}$ Ibid., 10.

3 Miguel Carbonell, "El neoconstitucionalismo: significado y niveles de análisis": 163-164; in: Miguel Carbonell and Leonardo García Jaramillo, eds., El canon neoconstitucional (Bogotá: Universidad Externado de Colombia, 2010).
} 
The cases in which the decisions of the CCC quoted the philosopher of egalitarian liberalism were the following: against censorship, ${ }^{4}$ in favor of abortion, ${ }^{5}$ in support of conscientious objection to obligatory military service ${ }^{6}$ in relation to an individual's choice of medical treatment, ${ }^{7}$ in defense of euthanasia as a personal decision regarding one's own death ${ }^{8}$ and in defense of the autonomy of the individual as the grounds for the secular state ${ }^{9}$ in the reintegration of a person with a disability to his job, ${ }^{10}$ and in extending the institution of marriage to same-sex couple. ${ }^{11}$ Finally, he was quoted in the context of defending the legal instruments for implementation of the peace agreement between the Colombian Government and Revolutionary Armed Forces of Colombia (FARC, for the acronym in Spanish) ${ }^{12}$ and demanding popular participation in the delimitation of a páramo (highland wilderness area). ${ }^{13}$ In addition, there are some decisions which refer to Dworkin for further explanation of different issues. ${ }^{14}$ And, paradoxically, there is a curious case referring to incest, ${ }^{15}$ in which the CCC makes a perfectionist's use of Dworkin's ideas. The particular quote in question is nonetheless mistakenly used, because it represents the philosopher as a spokesman for ideas that he attributes to communitarianism ${ }^{16}$.

This paper aims to describe how the Colombian Constitutional Court has utilized the political philosophy of Ronald Dworkin, showing that the use of the concepts of rights as trump cards, individual autonomy, and state neutrality, shape the reception of egalitarian liberalism. For this purpose, two different methodologies have been applied to it: on the one hand, an analysis of the concepts in the 21 decisions identified and, on the other hand, personal interviews of certain justices and law clerks of said court in order to validate the conclusions of the analysis and to contextualize the role of philosophy in the decisions of constitutional judges. To begin, it will present Dworkin's thoughts regarding the role of philosophy in judicial decisions.

\footnotetext{
${ }^{4}$ Colombian Constitutional Court (1996, no. C-045).

5 Colombian Constitutional Court (1994, no. C-133) and Colombian Constitutional Court (2006, no. C355).

${ }^{6}$ Colombian Constitutional Court (2014, no. T-314).

7 Colombian Constitutional Court (1994, no. T-401).

${ }^{8}$ Colombian Constitutional Court (1997, no. C-239).

9 Colombian Constitutional Court (1994, no. C-350).

10 Colombian Constitutional Court (2013, no. T-773).

11 Colombian Constitutional Court (2016, no. SU-214).

12 Colombian Constitutional Court (2017, no. C-174).

13 Colombian Constitutional Court (2017, no. T-361).

${ }^{14}$ Colombian Constitutional Court (2018, no. C-009), Colombian Constitutional Court (2018, no. T-468) and Colombian Constitutional Court (2018, no. SU-023).

${ }^{15}$ Colombian Constitutional Court (2012, no. C-241).

16 Ronald Dworkin, "Liberal Community," California Law Review 77 (1989).
} 


\section{SHOULD CONSTITUTIONAL JUDGES BE PHILOSOPHERS?}

\subsection{THE THEORETICAL PROBLEM}

Should our judges be philosophers? Can they be philosophers? These are questions that Ronald Dworkin asked when he was honored as Scholar of the Year of the New York Council for the Humanities. His answer, brief and somewhat disconcerting, was: "Judges have to be philosophers, but they cannot be and perhaps should not be [philosophers]". ${ }^{17}$ In the first place, they have to be philosophers since "the concepts that they utilize in their decisions (responsibility, meaning, intention, equality, freedom and democracy, for example) are difficult concepts that we are very far from clarifying fully or from wholly resolving what the best or most appropriate interpretation of them is, and it would be an error to think that our legislation, our history or our culture have unanimously agreed on a consideration that is, therefore, available for use by the judges, without any further analysis." Furthermore, they must "choose between the rival principles that are available to explain the constitutional concepts, and they must also be ready to present and defend the choices they make". ${ }^{18}$ In this way, "at some point in his career [...] Hercules must therefore consider the question not just as an issue of fit between a theory and the rules of the institution, but as an issue of political philosophy as well"19.

And Dworkin certainly defended a theorized approach to judicial decision, according to which "legal reasoning means bringing to bear on particular discrete legal problems [...] a vast network of principles of legal derivation or of political morality" 20 that lead to justifying "legal claims by showing that principles that support those claims also offer the best justification of more general legal practice in the doctrinal area in which the case arises". ${ }^{21}$ Dworkin applied the term justificatory ascent to this exercise of justification, which involved not only a philosophical exercise but a moral one as well, given that the Constitution is comprised of abstract moral principles that must be applied. ${ }^{22}$ Ultimately, according to Dworkin, "Judges and philosophers do not simply share overlapping topics and matters, as astronomers and astrologists do. On the contrary, the objectives and methods of judges include those of philosophers: both professions aim more precisely to formulate and better

\footnotetext{
17 Ronald Dworkin, "¿Deben nuestros jueces ser filósofos? ¿Pueden ser filósofos?" (Should our judges be philosophers? Could they be philosophers?), Estudios de Derecho 144 (2007): 15. All references to this lecture, which has not has yet been published in English, are our translation.

18 Ibid.: 33.

19 Ronald Dworkin, Taking Rights Seriously (Cambridge: Harvard University Press, 1978 ), 107.

20 Ronald Dworkin, Justice in Robes (Cambridge: Harvard University Press, 2006), 50.

${ }^{21}$ Ibid., 51-52.

22 Ibid., 122.
} 
understand the key concepts in which our predominant political morality and our Constitution are expressed." 23

The problem presents a paradox, which is that judges cannot and should not be philosophers because "it would be absurd to suggest that judges take leave of absence from their work in order to obtain doctoral degrees (PhDs) in philosophy, and that later, upon returning to the court, they write all their decisions, or at least the most important ones, in such a way as to be publishable in journals specialized in philosophy." 24 To put it differently, the fact that judges should know philosophy does not mean that their function is to philosophize. ${ }^{25}$

\subsection{THE PRACTICAL SOLUTION}

The relationship of philosophy to judicial decisions is complex and contradictory. Complex, because philosophy is not one of the primary resources that judges use in deciding a case. There are the constitutional and legal texts. Thus, the judges interviewed usually resort to philosophers or to legal theorists only when they must decide difficult cases, i.e., cases for which there is no previous ruling by the CCC. ${ }^{26}$ Likewise, most of the time they resort to them, indiscriminately in fact, as well as to other sources of law - particularly to comparative case law, or decisions of international organizations - only when they require additional argumentative support. ${ }^{27}$

On the other hand, various CCC justices are reluctant on principle to cite authors in their decisions ${ }^{28}$ since they consider that what they must interpret is only the political Constitution, for which reason they do not believe that "a judicial decision should be subject to the opinion or to the conceptual apparatus of a philosopher, because here the referent is the Constitution and not a theory that we may or may not like, but which does not form part of the Constitution", ${ }^{29}$ i.e. they are opposed to what a justice of the Spanish Constitutional Court calls the pretension of "patenting

\footnotetext{
${ }^{23}$ Ronald Dworkin, supra note 17: 18.

Ronald Dwor

kin, supra note 17: 18.

of various issues of Ronald Dworkin, see José M. Sauca, ed., El legado de Dworkin a la filosofía del derecho. Tomando en serio el imperio del erizo (Dworkin's legacy to the philosophy of law. Taking the hedgehog empire seriously) (Madrid, Centro de Estudios Políticos y Constitucionales, 2015).

${ }^{26}$ Interview with Aquiles Arrieta, Law Clerk of The Constitutional Court of Colombia, in Bogotá, Colombia (May 10, 2018), Interview by Iván Garzón Vallejo, Associate Professor, Universidad de La Sabana.

27 Interview with José Antonio Cepeda, Law Clerk in the Constitutional Court of Colombia, in Bogotá, Colombia (May 10, 2018), Interview by Iván Garzón Vallejo, Associate Professor, Universidad de La Sabana.

${ }^{28}$ Interview with Carlos Bernal, Justice in the Constitutional Court of Colombia, by e-mail (May 24, 2018), Interview by Iván Garzón Vallejo, Associate Professor, Universidad de La Sabana.

${ }^{29}$ Interview with Claudia Escobar, Law Clerk of The Constitutional Court of Colombia, by e-mail (May 31, 2018), Interview by Iván Garzón Vallejo, Associate Professor, Universidad de La Sabana.
} 
an author's constitution" 30 and to the philosophical temptation to love wisdom better than the law. ${ }^{31}$ This occurs not just for the hermeneutic reason mentioned above, but also because after the initial phase in the development of the CCC (1992-2001) an important corpus of precedents already existed, which led to a new era in which it was no longer necessary to cite authors in order to strengthen the ratio decidendi of the rulings, as had been the case during the early years of the CCC when the judges had to develop the foundational case law for the court. ${ }^{32}$

The paradox has yet another edge: there are two risks involved in the excessive or unnecessary quoting of certain authors - namely, the classics. The first is the risk of trivializing them, when their importance consists precisely of the fact that they inspire decisions that transcend the scope of any particular argument. The second one is that within the framework of the deliberation by the judges, the inclusion of a reference to an author whose doctrine is well-known - a natural law theorist, a liberal or a positivist author, for example - can sharpen the resistance of other judges to the argument proposed to obtain consensus, ${ }^{33}$ since, as Dworkin notes, "judges often disagree not simply about how some rule or principle should be interpreted, but whether the rule or principle one judge cites should be acknowledged to be a principle at all." ${ }^{\prime 3}$ Perhaps for both reasons - because the hermeneutics must flow directly from the constitutional text and because wielding an author's argument can hinder consensus - Dworkin himself asserted that it was necessary to keep philosophical theorizing cloaked, in the "dark."35

The relationship between philosophy and a judicial decision is also contradictory because the influence of philosophy may be greater than what the quotes in the rulings reveal. Indeed, in the case of the $\mathrm{CCC}$, the Hart-Dworkin debate served in the first era of the institution (1992-2001) to question the traditional model of syllogistic interpretation of law and to propose an anti-formalist model that vindicated the principles and discretionary authority of judges to turn to the best sources of law to resolve the case. ${ }^{36}$ Diego López points out that Dworkin's influence and his antiformalist perspective had a notable impact in Colombian universities. After the decade of the sixties, the new "Anglo-Saxon anti-formalism was the equivalent of a countercultural and counterhegemonic, academic and anti-professionalizing, as well

\footnotetext{
30 Interview with Andrés Ollero, Justice in the Constitutional Court of Spain, in Madrid, Spain (December 7, 2015), Interview by Iván Garzón Vallejo, Associate Professor, Universidad de La Sabana.

31 Michael Walzer, supra note 1.

32 Interview with Aquiles Arrieta, supra note 26

33 Interview with Cristina Pardo, Justice in the Constitutional Court of Colombia, in Bogotá, Colombia (May 10, 2018), Interview by Iván Garzón Vallejo, Associate Professor, Universidad de La Sabana.

34 Ronald Dworkin, supra nota $19,122$.

35 Ronald Dworkin, supra note 20, 73.

36 Interview with Aquiles Arrieta, supra note 26.
} 
as a moderately progressive version of the role that law should play in the social conflict in countries like Argentina first, and then Colombia."

The CCC clearly revealed that anti-formalist Dworkinian influence in 2001 when, in analyzing the principle of non-incrimination, it explained that the American professor thinks that "the legal system does not just consist of standards that function as rules, but that it is also possible to find others in it that operate as «principles»". ${ }^{38}$ That is an essential element in his debate with Hart, in that "the model of judicial decisions based on principles, for Dworkin, explains and properly justifies the role of judges in a democratic state under the rule of law". ${ }^{39}$

In the subsequent part of this article we consider whether, in the case of Ronald Dworkin, his influence on the jurisprudence of the CCC is supported by explicit references or not. The personal interviews with justices and law clerks of the CCC enabled us to corroborate that the relationship between philosophy and judicial decision is, in fact, complex and contradictory. Similarly, if one rapidly evaluates whether the use of philosophy in judicial decisions contributes to the three objectives pointed out by the American philosopher, one would have to indicate, regarding the first of these, that it does contribute partially to the familiarity of judges and lawyers with the philosophical culture; regarding the second, that it does not reduce the controversy among the judges themselves; and regarding the third, that it does make said controversy more respectable and enlightened, but only in cases in which that resource is necessary. ${ }^{40}$

\section{RONALD DWORKIN IN THE COLOMBIAN CONSTITUTIONAL COURT}

\subsection{HERCULES, THE PHILOSOPHER JUDGE}

The political philosophy of Ronald Dworkin is an eloquent demonstration of the fact that liberalism is a philosophical family, not an ideology or a monolithic doctrinaire corpus. For that reason, egalitarian liberalism and ethical or perfectionist liberalism coexist within it.

Equality is the organizing principle of egalitarian liberalism, unlike other perspectives of the same philosophical family that focus on maximizing happiness or on a type of freedom closely linked to private property. ${ }^{41}$ It also supposes a

\footnotetext{
37 Diego López, "Kelsen, Hart y Dworkin en Hispanoamérica: condiciones de posibilidad de una filosofía local del Derecho" (Kelsen, Hart and Dworkin in Hispanic America: conditions of possibility of a local philosophy of Law): 420; in: Enrique Cáceres, ed., Problemas contemporáneos de la filosofía del Derecho (México: UNAM, 2005).

38 Colombian Constitutional Court (2001, no. C-1287).

39 César Rodriguez, La decision judicial (The judicial decision) (Bogotá: Siglo del Hombre, 1997), 17.

40 Ronald Dworkin, supra note 17, 18.

41 Steven H. Shiffrin, "Liberalism, Radicalism, and Legal Scholarship," UCLA Law Review (1983): 1103.
} 
distributive form of justice and equality of resources. ${ }^{42}$ Therefore, the liberal conception of equality is the essence of Dworkinian liberalism. ${ }^{43}$ Equality of resources is necessary so that each one can assume the ethical challenges of what they consider a good life. Thus, according to the challenge model proposed by the author, the possibility of my life being good depends on my having a just portion of resources to pursue my critical interests, and that portion will be just if it is egalitarian. For all of these reasons, the challenge model may be considered sufficient support for Dworkinian liberal equality. ${ }^{44}$

For Dworkin, the element that defines liberalism is the fundamental value of treating all of its citizens as equals, maintaining the neutrality of the state on questions relating to the good life. ${ }^{45}$ For this reason, he warns that "a political community has no moral power to create and enforce obligations against its members unless it treats them with equal concern and respect", ${ }^{46}$ and for that reason, treating people as equals is much more a principle of morality than of ethics: it means that no life is more important than any other. ${ }^{47}$

This being so, "no one would have to abandon or to amend the convictions described thus far, while these convictions affect their ethical beliefs in first person: their beliefs about the type of life that is suitable or optimum for them [our translation]". However, the problem appears when "people also have ethical considerations in third person about the optimum life for others" [our translation], ${ }^{48}$ i.e., when our responsibility to do the best for ourselves collides with what we should do for others. ${ }^{49}$ Ethical liberals, Dworkin notes, may campaign in favor of what they consider to be good, but "liberal equality denies them one weapon: even if they are in the majority, they must not forbid anyone to lead the life he wants, or punish him for doing so, just on the ground that they think his ethical convictions are wrong". ${ }^{50}$ In this context, liberal tolerance becomes the political guarantee of neutrality. ${ }^{51}$

For the strategy of continuity, it is important that ethical liberals do not feel aggrieved by that liberal tolerance, "that they not feel that they have compromised, or left aside, or placed in parenthesis their own convictions when they decide not to impose them, at the least opportunity, upon a dissenting minority" [our

\footnotetext{
42 Emily Sherwin, "How liberal is liberal equality? A Comment on Ronald Dworkin's Tanner Lectures," Legal theory (1995): 227.

43 Ronald Dworkin, Una cuestión de principios (A matter of principle) (Buenos Aires: Siglo Veintiuno Editores, 2012), 233.

44 Matthew Clayton, "Liberal Equality and Ethics," Ethics 3 (2002): 8.

45 Patrick Neal, "Liberalism \& Neutrality," Polity 17 (1985): 664.

46 Ronald Dworkin, Justice for Hedgehogs (Cambridge: Harvard University Press, 2011 ), 333.

47 Stephen Guest, Ronald Dworkin (California: Stanford University Press, 2013), 162.

48 Ronald Dworkin, Ética privada e igualitarismo político (Barcelona: Paidós, 1993), 191.

49 Stephen Guest, supra note 47, 161.

50 Ronald Dworkin, "Foundations of Liberal Equality": 302; in: S. Darwall, ed., Equal Freedom: Selected

Tanner Lectures on Human Values (Ann Arbor: University of Michigan Press, 1995).

51 Ronald Dworkin, supra note 48, 193.
} 
translation]. ${ }^{52}$ Some authors have criticized this perspective of individual tolerance united to state neutrality, warning that a mild form of tolerant perfectionism would fit better with the fundamentals of egalitarianism defended by Dworkin, ${ }^{53}$ but our author ultimately takes the side of a state that renounces official models of the good life and remains neutral in the moral field, leaving individuals to decide for themselves on these questions. ${ }^{54}$

Along these lines, the reading of Dworkin in the CCC is basically that of an egalitarian liberalism that advocates for the moral neutrality of the state and, correlatively, for the defense of the autonomy of the individual. Nevertheless, such autonomy has its limits, since not all modes of life are equally decent or worthy. In this sense, Ronald Dworkin proposes a conception of what is good that is fundamental to liberal political ideas ${ }^{55}$ and rejects the discontinuity between the conceptions of the good life in the discussion about justice. It is a comprehensive ethical liberalism that integrates ethics, morality and justice, ${ }^{56}$ that rejects moral skepticism as well as axiological relativism, and vindicates objective values in the individual responsibility to live well, which is a burden that is imposed upon us "by the bare fact of our existence as self-conscious creatures with lives to lead." ${ }^{157}$

This conception is framed within "the strategy of continuity," the antagonist of which is the political liberalism of John Rawls, which is framed in turn within the "strategy of discontinuity." 58 One consequence of the continuity between ethics, morality, and justice is that citizens participate in the public sphere without renouncing their commitment to their ethical, philosophical and religious convictions. It thus appeals to "people who want a more integrated moral experience, who want their politics to match their convictions about what it is to live well, rather than requiring them to set these convictions aside, to check them at the voting-booth door" (Dworkin 1995, 207), thereby contradicting the initial Rawlsian proposal of public reason, which stipulates that when citizens vote they should adapt their decision to the political conception of justice. ${ }^{59}$

The Dworkinian strategy of continuity correlates with "the model of challenge," which "adopts Aristotle's view that a good life has the inherent value of a skillful performance. So it holds that events and achievements and experiences can have

\footnotetext{
52 Ibid., 196.

53 Colin M. Macleod, "Liberal Neutrality or Liberal Tolerance?" Law and Philosophy (1997): 529.

54 Ronald Dworkin, Religion Without God (Cambridge-London: Harvard University Press, 2014 ), 130.

55 William R. Lund, "Politics, Citizens, and the Good Life: Assessing Two Versions of Ethical Liberalism," Political Research Quarterly 49 (1996): 479.

56 James E. Fleming \& Linda C. McClain, "Dworkin's Perfectionism," Boston University School of Law, Public Law \& Legal Theory Working Paper (2015): 1.

57 Ronald Dworkin, supra note 46, 196.

58 Ronald Dworkin, supra note 50, 205.

59 For Ronald Dworkin's and the communitarian philosophers' critique of the Rawlsian concept of public reason, see Iván Garzón Vallejo, La religión en la razón pública (Religion in public reason) (Buenos AiresBogotá: Editorial Astrea-Universidad de La Sabana, 2014).
} 
ethical value even when they have no impact beyond the life in which they occur"60 and they obey two principles: self-respect, i.e., the responsibility to take our life seriously so that it becomes a successful undertaking ${ }^{61}$ and authenticity, which consists of living "in response, rather than against the grain of, your situation and the values you find appropriate". ${ }^{62}$ This proposal is opposed by the "model of impact," which "holds that the ethical value of a life - its success in the critical sense- is entirely dependent on and measured by the value of its consequences for the rest of the world." $" 63$

Although these models differ in their ideas of the good life, whether due to the impact it has on others or due to its ethical value, even though it only affects personal life understood as challenge and art of living ${ }^{64}$, in both cases the success of a life is understood in a critical rather than a volitional sense, for its realization rather than for its results. The difference between these two concepts is rooted in the fact that "someone's volitional well-being is improved, and just for that reason, when he has or achieves what in fact he wants. His critical well-being is improved by his having or achieving what he should want, that is, the achievements or experiences which would make their life a worse one not to want." ${ }^{\prime 65}$ In short, something is in the critical interests of someone if it makes the life of that person a better life to be lived. ${ }^{66}$

As we will show, almost all of the decisions in which the CCC has cited Ronald Dworkin have had the purpose of limiting the action of the collectivity as opposed to the individual and neutralizing the power of the state or of the majorities in three ways: by appealing to rights as trump cards, defending individual autonomy, and demanding skepticism on the part of the state with respect to arguments of public morality or of a religious nature.

We will now undertake an analysis of the decisions on the basis of these three aspects. We will then present their exceptional use in a decision which deviates from the dominant interpretation and is based on a hermeneutical error.

\subsection{RIGHTS AS TRUMP CARDS}

For the purpose of protecting the individual from the collectivity, Dworkin is quoted in several decisions in which the majoritarian premise is rejected and the contrary idea, which he has called the "constitutional conception of democracy" is

\footnotetext{
60 Ronald Dworkin, supra note 50, 244.

61 Ronald Dworkin, supra note 46.

62 Ibid., 210.

63 Ronald Dworkin, supra note 50, 242.

64 Ronald Dworkin, supra note 46, 198.

65 Ronald Dworkin, supra note 50, 230.

66 Bernard Williams, "Dworkin on Community and Critical Interest," California Law Review 77 (1989): 515.
} 
adopted. ${ }^{67}$ Some of them resort to the concept of trump cards, for example, so as to guarantee the right to due process for a convict whose constitutional rights have been violated, asserting that "fundamental rights are true trump cards against the collective welfare." 68 At the same time, the majoritarian argument is attacked because it is believed that "conditioning the validity of a constitutional right to the criteria of majorities is to deprive it of all its specific efficacy." 69

The CCC explains the concept of trump cards in the following way:

In card games like King or Bridge, one of the suits (diamonds, spades, hearts and clubs) is chosen as trump, and from then on any one of the numbers and figures of that suit, no matter how low, has greater value and prevails over even the highest number or figure of the other suits. The image created by Dworkin reflects perfectly the sense of his proposal of taking rights seriously, and of considering them "trumps" over state power. ${ }^{70}$

This concept also appears in the defense of the right to work of a citizen with a disability, where "the discussion that took place regarding the case recalls a metaphor coined by the philosopher of law Ronald Dworkin, according to whom rights are trump cards. In this way, the author places the efficacy of rights above political decisions"71 and this coincides with his distinction between individual rights and collective interests, ${ }^{72}$ according to which, the courts, understood as the "forum of principles, ${ }^{173}$ are responsible for protecting such rights, while the legislatures are responsible for promoting the interests of the collective. ${ }^{74}$ Accepting this distinction in the case of the CCC, the control that it exercises over the laws would mean the anticipated triumph of individual rights over collective interests.

The same approach appears at the moment of rejecting the majoritarian argument in the decision on presidential re-election, for, as a dissident court justice affirms, political decisions cannot overstep individual rights despite having generalized support: "with much foundation, Dworkin points out that for there to be a real constitutional democracy, it is necessary that some relational conditions of democracy exist, which are no other than the way in which an individual or minority group must be treated by the majority in order to be a moral member of the community." 75

\footnotetext{
67 Ronald Dworkin, Freedom's Law (Cambridge: Harvard University Press, 1997), 17.

68 Colombian Constitutional Court (1996, no. T-669).

${ }^{69}$ Ibid.

70 Colombian Constitutional Court, supra note 10.

${ }^{71}$ Ibid.

72 Ronald Dworkin, supra note 19, 90.

${ }^{73}$ Ronald Dworkin, "The Forum of Principles," New York University Law Review (1981): 59.

74 For a critique of said distinction, see Robert P. George, Making Men Moral (Oxford: Oxford University Press, 2002), 85.

75 Colombian Constitutional Court (2005, no. C-1041).
} 
This perspective can be found in Taking Rights Seriously and it is also present in the debate between freedom of expression and public security. The justices that distanced themselves from the defense of a presidential decree that prohibited the dissemination of communiqués from criminal organizations through the mass media argued that the defense of a collective good must be done within the framework of respect for fundamental rights (information, expression), and that the decree was disproportionate in the application of exceptional measures. For this reason, they noted, "some authors define constitutional rights as limitations on the pursuit of general objectives and collective rights. ${ }^{176}$

Conscientious objection to obligatory military service was another situation that revealed the tension between individual rights and collective security. When the CCC recently entered into this discussion, the supremacy of rights was a key argument in favor of personal freedom over the needs of the collective, in concrete terms, to defend the individual in the tension that arises between a moral right and a legal duty: "the central question to resolve then, is summed up in how to deal with the conflict between conscience and obligation, which necessarily concerns the double dimension of what is at the same time a moral right and a legal duty with respect to the state."77 The Dworkinian solution to this conflict was the following:

This apparent collision, for the Court, in some cases must be resolved in favor of the person, for it is indisputable that in a pluralistic society founded on respect for human dignity, people should not be obliged to carry out actions that are contrary to the most profound convictions of their conscience. It is a space that is restricted or immune to coercion, inherent to the person due to their rational condition, and it implies that no thought or action may be imposed on persons with diverse worldviews that define their personality, to such an extent that it renders them incompatible with what the law prescribes, particularly with respect to military discipline in which the use of force is an essential element. ${ }^{78}$

As can be seen, in this case the argument in favor of the need to provide security for the community did not prevail over that of the individual right to autonomy.

\subsection{THE PRIMACY OF INDIVIDUAL AUTONOMY}

The second concept is that of individual autonomy, from which the concept of self-creation is derived. ${ }^{79}$ The CCC used it to analyze the case of a patient who chose

\footnotetext{
76 Colombian Constitutional Court, supra note 4.

77 Colombian Constitutional Court, supra note 6.

78 Ibid.

79 Ronald Dworkin, "Naturaleza contra autocreación" (Nature against autocreation), El País (March 1997)

// http://elpais.com/diario/1997/03/17/sociedad/858553210_850215.html.
} 
a medical treatment that was different from the one he was going to be given at the hospital. In this respect, the CCC points out that:

Recognizing the individual right to autonomy -says R. Dworkin- makes selfcreation possible. It allows each one of us to be responsible for forming our own lives in accordance with our personality, coherent or incoherent, but nonetheless distinctive. It allows us to lead our lives instead of being guided in order that each one of us can be what we wish to be. We allow a person to choose death instead of an amputation, or a transfusion, if that is an informed wish, for we recognize his right to a life structured in accordance with his values. ${ }^{80}$

In the decision, this position is opposed to the paternalistic option according to which doctors should make the best decision for the patient's health, regardless of the latter's own wishes. The final decision is in favor of the autonomist perspective, establishing certain conditions such as informed consent.

The author's understanding of community is based on a restrictive perspective of communal life ${ }^{81}$ and privileges the autonomy of individuals, "that is, a right to make important decisions defining their own lives for themselves. ${ }^{\prime 82}$ This conclusion assumes that public decisions do not make moral judgments, but rather that, under the condition of neutrality, such decisions are made in favor of autonomous individuals, respecting a just equality, because the notion of justice demands parity of circumstances and resources: "the law is plainly part of people's circumstances, and circumstances are plainly unequal when the law forbids some to lead the lives they think best for them only because others disagree." 83 In this way, we may conclude, self-respect and authenticity are both honored, which are, in turn, conditions of dignity.

The same reference to Dworkin was used in another decision ${ }^{84}$ to guarantee that an indigenous inmate would receive vernacular medical treatments while in jail. The concept of individual autonomy is also relevant in two decisions on decriminalization of abortion. In the 1994 decision that upheld penalization, the dissenting opinion referred to - Life's Dominion - in order to affirm that "the doctrine based on the defense of the right of privacy, adopted by the US Supreme Court in the case of Roe $v$. Wade, recognizes a woman's right to decide, during the first trimester of pregnancy - a term system - whether she wishes to continue or to

\footnotetext{
${ }^{80}$ Colombian Constitutional Court, supra note 7.

81 Ronald Dworkin, La comunidad liberal (Liberal community) (Bogotá: Siglo del hombre, 1996), 176.

82 Ronald Dworkin, Life's Dominion: An Argument About Abortion, Euthanasia, and Individual Freedom (New York: Vintage Books, 1993), 222.

83 Ronald Dworkin, supra note 50.

84 Colombian Constitutional Court (1997, no. C-214).
} 
terminate it, without risk to her own life, resorting to the medical services of the state, with which the woman is left free to decide on this moral option." 85

Life's Dominion is quoted again in the 2006 decision that decriminalized the practice of abortion in three circumstances to justify a woman's freedom to choose whether to terminate her pregnancy:

Women need the freedom to make decisions on reproductive matters not only through the right to be left in peace, but, often, to strengthen their ties to others: in order to responsibly plan a family for which to provide, to continue fulfilling the professional or labor obligations contracted with the outside world, or to continue supporting their families and communities. ${ }^{86}$

As can be seen, a woman's dilemma of whether to terminate or to continue her pregnancy must be institutionally resolved with a view to protecting her autonomy. Therefore, in this and in other cases, individual autonomy supports the supremacy of individual rights in a liberal society. The individual may not be bullied by the majorities or by public authorities, much less when decisions regarding her critical interests are at stake.

The CCC explains that democracy is not defined by the supremacy of majority decisions but rather by equality. If the decisions of the majority ensure that equality, they can be considered democratic; otherwise, it is possible to resort to other mechanisms. That was one of the considerations for extending the institution of marriage to same-sex couples:

A democratic system, according to Dworkin, means "government subject to conditions [...] of equality of status for all citizens." If majoritarian institutions provide these conditions, the verdict should be accepted by everyone, but when they are not provided, "there can be no objection, in the name of democracy, to other procedures that protect and respect them better". ${ }^{87}$

In the same decision, the CCC draws support from the text of Freedom's Law ${ }^{88}$ to show that democratic deliberation is understood as the process in which citizens seek to influence collective decisions from the standpoint of their own interests "and in the freedom to choose the type of life that is most valuable to them, ${ }^{\prime 89}$ which means that although they all participate based on their ethical conceptions, the result should guarantee moral autonomy.

\footnotetext{
85 Colombian Constitutional Court, supra note 5.

${ }^{86}$ Colombian Constitutional Court (2006, no. C-355).

87 Colombian Constitutional Court, supra note 11.

88 Ronald Dworkin, supra note 67.

89 Colombian Constitutional Court, supra note 11.
} 


\subsection{STATE NEUTRALITY, THE GUARANTEE OF SECULARISM}

In 2011, the CCC once again wielded the Dworkinian argument presented in Taking Rights Seriously in studying the claim brought against First Law of 1952, which officially consecrated the country to the Sacred Heart of Jesus, in order to explain that the majoritarian principle cannot be imposed in religious matters in a democratic society:

A fundamental right can be limited by other concurring fundamental rights or by constitutional values in conflict, but not by the conceptions prevailing among the majorities. In fact, conditioning the validity of a constitutional right to the criteria of the majorities is to deprive it of all its specific effectiveness since, to a great extent, fundamental constitutional rights are the promises that majorities make to minorities -and to those radical minorities that are individual persons- that their dignity and equality will be respected. ${ }^{90}$

Almost two decades later, the CCC quoted Dworkin once again to defend the secularism of the state in response to a claim of unconstitutionality regarding a law that declared a municipality and its cathedral to be a Sanctuary. There, the CCC made use of the distinction the author establishes in Is Democracy Possible Here? Principles for a New Political Debate, between the following two types of democratic societies with respect to religion:

(i) Tolerant religious societies, which consider that religious practice, considered in itself, must be protected by the state, but which allow it to be expressed through diverse creeds, or even tolerate it when citizens do not profess any religion; and (ii) Secular societies, which accept the religious practices of their citizens, or the lack thereof, but not because they consider religions to be a constitutionally protected sphere in itself, but inasmuch as such practices are part of the autonomy of the individual, who may opt for any type of ethical or moral parameter to guide their own conduct, including one of a transcendent or religious nature. ${ }^{91}$

Said decision assumes the model of secular society as guarantor of the autonomy of the individual and demands moral neutrality of the state, which is coherent with the idea of tolerance towards all peaceful religious creeds as well as toward the people who do not profess any faith. ${ }^{92}$ Even the conservative justices endorsed the same author on the separation between a committed ethical life in the private sphere and neutrality in public decisions. In distancing themselves from a decision in favor of euthanasia, they offered the following explanation:

\footnotetext{
90 Colombian Constitutional Court, supra note 9.

91 Colombian Constitutional Court (2011, no. C-817).

92 Ronald Dworkin, La democracia posible (Is Democracy Possible Here?) (Barcelona: Paidós, 2008), 78.
} 
There is no doubt that our constitutional model corresponds to that of a nonconfessional and pluralistic state in which the ethical foundation of rights is not generally grounded on the basis of maximums. This option, in contrast, does fit in the field of culture and society for those people who identify with different religious, social or personal worldviews that are nourished by more demanding moral parameters. Nevertheless, this is not sufficient reason to simply embrace the distinction attributed to Ronald Dworkin, in a different normative context, because in our case, it is the Colombian Constitution itself and not a religious authority, that abounds in pro-life provisions which constitute a very dense and demanding protective spectrum, that may be less than the one prescribed by religious worldviews, but which is nonetheless especially intense. ${ }^{93}$

It is evident from the decisions analyzed above that the CCC considers references to Dworkin to be instrumental in the defense of state neutrality regarding moral and religious matters. Furthermore, this neutrality is framed within a liberalism that superposes the individual over the community by considering individuals' rights to be trump cards and individual autonomy to be of greater value than public morality and the religion of the majority. But, at the same time, the fundamentals of religious freedom are grounded on moral freedom, ${ }^{94}$ i.e., on the right to ethical independence, of which religious freedom is but an imperfect preview. ${ }^{95}$

This being so, it is only logical that egalitarian liberalism would be institutionally framed in neutrality, since different projects of the good life must be treated with equal consideration and respect. Treating them in this way is, according to Guest, the foundational principle of Dworkin's moral and political theory. ${ }^{96}$ Following this perspective, public authorities should not privilege any ethical proposal the veracity or falsity of which can be reasonably debated, i.e., as long as they are compatible with the fundamental ideas implicit in a democratic society. ${ }^{97}$

The strategy of continuity between ethics and politics proposed by Ronald Dworkin and that of discontinuity proposed by John Rawls both defend the neutrality of the state in moral and religious matters. ${ }^{98}$ The difference lies in the fact that, while the former does so as the result of a process, the latter assumes it as a point of departure and a methodological axiom. ${ }^{99}$ Both authors, influenced by Isaiah Berlin, consider neutrality to be necessary to achieve peace, since plurality of values - an

\footnotetext{
93 Colombian Constitutional Court, supra note 8.

94 Ronald Dworkin, supra note 54.

95 For a critique of this idea, see Iván Garzón Vallejo, "Dworkin and Religious Beliefs as a Right to Ethical Independence," Telos 183 (2018) // DOI: 10.3817/0618183253.

96 Stephen Guest, supra note 47, 19.

97 Andrew Koppelman, "Ronald Dworkin, Religion, and Neutrality," Boston University Law Review (2014):

1241.

98 Ronald Dworkin, supra note 48, 189.

99 Ibid., 66.
} 
indisputable fact of life in liberal societies - excludes the possibility of finding one monolithic scheme in which all of them can be lived, not abandoned.

\subsection{DWORKIN THE COMMUNITARIAN?}

There was a different reception of Dworkin in the 2012 decision that declared the constitutionality of criminalizing incest. ${ }^{100}$ The issue had been addressed by the CCC years before, and on that occasion there was a citizen's intervention carried out by Professor Guillermo Hoyos Vásquez, who synthesized the Dworkinian analysis in Liberal Community and argued on behalf of the integrationist position, according to which "liberal tolerance depends on an illegitimate distinction between the lives of the individuals of the community and the life of the community as a whole. From this perspective, the goodness of life value for any citizen is just a reflection and function of the value of the life of the community in which he lives". ${ }^{101}$

Nonetheless, the CCC assumed a different position in its decision of 2012 in which, relying on Dworkin, it defended the majoritarian argument against incest. It held that:

The criminalization of incest assumes a majoritarian position in Colombia that considers this conduct to be harmful to the family, as a legal entity. The crime of incest thus reflects a generalized viewpoint that rejects sexual relations between relatives in as much as it undermines the type of relationships and values that should be formed within the family. ${ }^{102}$

This argument is accompanied by a footnote in which the text Liberal Community is cited again to explain that Dworkin "tackles the question of whether conventional ethics can be imposed by means of criminal law, based on an analysis of the Bowers v. Hardwick case, in which the US Supreme Court upheld the constitutionality of criminalizing sodomy. The ruling held that individuals' lives depend on what they provide for the welfare of their community: "people should identify their own interests with those of the political community to which they belong". ${ }^{103}$ The error stems from the fact that the CCC attributes certain theses to Dworkin, which he actually attributes to communitarians, and regarding which he develops a harsh critique.

For that reason, this interpretation of Dworkin's work deviates from that which the CCC has developed in its other decisions. Further on, it states that "penal norms must contribute to the formation of citizens who are respectful of the rights of others, for which reason the penalization of incest is justified by virtue of its usefulness as

\footnotetext{
100 Colombian Constitutional Court, supra note 15.

101 Colombian Constitutional Court (1998, no. C-404).

102 Colombian Constitutional Court, supra note 15.

103 Ibid.
} 
an instructive element of respect for the family and the rights of its members", 104 and it refers to Dworkin once again with a footnote explaining that "according to Dworkin, the community is an association in which each individual is concerned with the welfare of others as if it were their own concern." ${ }^{105}$ This last idea is found in Liberal Community, not as one of Dworkin's own theses, but rather as an explanation of the second communitarian argument: paternalism. ${ }^{106}$

Finally, the ruling insists on presenting a defense of the community over the individual when it says that the "protection of the family stands out as a matter of public interest among citizens concerned not only about their individual interest but also about the protection of their community through the protection of its families."107 Another footnote explains that:

this perspective assumes the position that Dworkin denominates "integration with the community." In that essay he refers to the critique of liberal tolerance since it would establish a sharp division between the welfare of individuals and that of the political community to which they belong. The life of the individual and that of the community are integrated, so that the critical success of individual lives constitutes an aspect of the goodness of the community as a whole. ${ }^{108}$

\section{CONCLUSIONS}

This article draws several conclusions, as articulated in the final paragraphs below.

The use of Ronald Dworkin in the jurisprudence of the CCC operated in two ways: one, explicit, and three other, implicit. The former refers to the decisions in which his different works were quoted, in which he served as a point of support in rulings that articulated the rights, autonomy and neutrality of an egalitarian liberal interpretation. The latter, because his debate with Herbert Hart served in a first period of the CCC (1992-2001) to question the traditional model of syllogistic interpretation of law and to propose an anti-formalist model that vindicated the principles and the judicial discretion of judges to turn to sources of law that are suitable for solving the case.

In the explicit use the CCC makes of Ronald Dworkin's ideas, three concepts appear repeatedly: rights, individual autonomy and state neutrality. Rights are conceived in an individualistic and egalitarian way as political and historical conquests, trump cards that the individual vindicates in the face of any attempt on 
the part of the state and sociological majorities to impose a moral conception. At the same time, individual rights are compatible with the ethical ways of life that each one chooses. Autonomy, in this sense, is the capacity for self-determination in choosing one's own critical interests and the best way of living one's life. State neutrality is a demand for public authorities not to intervene in the sphere of ethical decisions of individuals, to avoid the political validation of a majoritarian moral conception.

The CCC's explicit use of Ronald Dworkin is functional because the decisions analyzed have extracted from his work only those concepts and ideas that would contribute to elevating the level of argumentation in the ratio decidendi in the ruling. This was corroborated in several interviews in which the justices and law clerks of the CCC confirmed the fact that they usually cite an author only in as much as it contributes theoretical elements to help resolve a case that would otherwise require new enlightening elements. This functional use is opposed to a contextual use, in which the author's work is read with its internal tensions, separating circumstantial aspects from the general principles in its propositions, which would avoid an unequivocal reading lacking in nuances, but would be more appropriate for a philosophical treatise than for a judicial decision.

Of the three objectives pointed out by Ronald Dworkin regarding the effect of judges incorporating philosophy into their rulings, two of them are fulfilled in the CCC: the first - to contribute to judges' and lawyers' familiarity with the philosophical culture, and the third (although conditional) - makes the controversy more respectable and enlightened. Various CCC justices have agreed in concluding that the second objective - that of reducing controversy among the justices themselves - has not been fulfilled. This is because the different justices' philosophical positions are usually known to their colleagues. ${ }^{109}$ So, while quoting certain authors may strengthen the ideological position of their argumentation, it may also increase their opponent' prejudices towards them. ${ }^{110}$

\section{BIBLIOGRAPHY}

1. Carbonell, Miguel, and Leonardo García. El canon neoconstitucional (The neoconstitutional canon). Bogotá: Universidad Externado de Colombia, 2010.

2. Clayton, Matthew. "Liberal Equality and Ethics." Ethics 113 (2002): 8-22 // DOI: $10.1086 / 341324$. 
3. Dworkin, Ronald. "¿Deben nuestros jueces ser filósofos? ¿Pueden ser filósofos?" (Should our judges be philosophers? Could they be philosophers?). Estudios de Derecho 144 (2007): 16-36.

4. Dworkin, Ronald. "The Forum of Principles." New York University Law Review (1981): 469-518.

5. Dworkin, Ronald. Ética privada e igualitarismo político (Private ethics and political egalitarianism). Barcelona: Paidós, 1993.

6. Dworkin, Ronald. "Foundations of Liberal Equality": 190-306. In: S. Darwall, ed. Equal Freedom: Selected Tanner Lectures on Human Values. Ann Arbor: University of Michigan Press, 1995.

7. Dworkin, Ronald. Freedom's Law. Cambridge: Harvard University Press, 1997.

8. Dworkin, Ronald. Justice for Hedgehogs. Cambridge: Harvard University Press. 2011.

9. Dworkin, Ronald. Justice in Robes. Cambridge: Harvard University Press, 2006.

10. Dworkin, Ronald. La comunidad liberal. Bogotá: Siglo del Hombre, 1996.

11. Dworkin, Ronald. La democracia posible (Is Democracy Possible Here?). Barcelona: Paidós, 2008.

12. Dworkin, Ronald. "Liberal Community." California Law Review 77 (1989): 479594.

13. Dworkin, Ronald. Life's Dominion: An Argument About Abortion, Euthanasia, and Individual Freedom. New York: Vintage Books, 1993.

14. Dworkin, Ronald. "Naturaleza contra autocreación" (Nature against autocreation), El País (March 16, 1997) // http://elpais.com/diario/1997/03/17/sociedad/858553210_850215.html.

15. Dworkin, Ronald. Religion without God. Cambridge-London: Harvard University Press, 2014.

16. Dworkin, Ronald. Taking Rights Seriously. Cambridge: Harvard University Press, 1978.

17. Dworkin, Ronald. Una cuestión de principios (An Matter of Principles). Buenos Aires: Siglo Veintiuno Editores, 2012.

18. Fleming, James, and Linda McClain. "Dworkin's Perfectionism." Boston University School of Law, (2015): 1-22.

19. Garzón Vallejo, Iván. "Dworkin and Religious Beliefs as a Right to Ethical Independence." Telos 183 (2018): 253-255 //

DOI: $10.3817 / 0618183253$.

20. Garzón Vallejo, Iván. La religión en la razón pública (Religion in public reason). Buenos Aires-Bogotá: Editorial Astrea-Universidad de La Sabana, 2014.

21. George, Robert. Making Men Moral. Oxford: Oxford University Press, 2002. 
22. Guest, Stephen. Ronald Dworkin. California: Stanford University Press, 2013.

23. Interview with Aquiles Arrieta, Law Clerk of The Constitutional Court of Colombia, in Bogotá, Colombia (May 10, 2018). Interview by Iván Garzón Vallejo, Associate Professor, Universidad de La Sabana.

24. Interview with Andrés Ollero, Justice in the Constitutional Court of Spain, in Madrid, Spain (December 7, 2015). Interview by Iván Garzón Vallejo, Associate Professor, Universidad de La Sabana.

25. Interview with Carlos Bernal Pulido, Justice in the Constitutional Court of Colombia, by e-mail (May 24, 2018). Interview by Iván Garzón Vallejo, Associate Professor, Universidad de La Sabana.

26. Interview with Claudia Escobar, Law Clerk of The Constitutional Court of Colombia, by e-mail (May 31, 2018). Interview by Iván Garzón Vallejo, Associate Professor, Universidad de La Sabana.

27. Interview with Cristina Pardo, Justice in the Constitutional Court of Colombia, in Bogotá, Colombia (May 10, 2018). Interview by Iván Garzón Vallejo, Associate Professor, Universidad de La Sabana.

28. Interview with José Antonio Cepeda, Law Clerk in the Constitutional Court of Colombia, in Bogotá, Colombia (May 10, 2018). Interview by Iván Garzón Vallejo, Associate Professor, Universidad de La Sabana.

29. Koppelman, Andrew. "Ronald Dworkin, Religion and Neutrality." Boston University Law Review 94 (2014): 1241-1253.

30. López, Diego. "Kelsen, Hart y Dworkin en Hispanoamérica: condiciones de posibilidad de una filosofía local del Derecho": 415-457. En "Problemas Contemporáneos de la Filosofía del Derecho" (Kelsen, Hart and Dworkin in Hispanic America: conditions of the possibility of a local philosophy of Law. From Contemporary Problems of Law Philosophy). Mexico. UNAM, 2005.

31. Lund, William. "Politics, Citizens and the Good Life: Assessing Two Versions of Ethical Liberalism." Political Research Quarterly 49 (1996): 479-504 // DOI: $10.1177 / 106591299604900302$.

32. Macleod, Colin. "Liberal Neutrality or Liberal Tolerance?" Law and Philosophy 16 (1997): 529-559 //DOI: 10.2307/3505019.

33. Neal, Patrick. "Liberalism and Neutrality." Polity 17 (1985): 664-684 // DOI: $10.2307 / 3234569$.

34. Rodríguez, César. La decisión judicial (The judicial decision). Bogotá: Siglo del Hombre, 1997.

35. Sauca, José M. El Legado de Dworkin a la filosofía del Derecho. Tomando en serio el imperio del erizo (Dworkin's legacy in philosophical law. Taking seriously 
hedgehogs' imperialism). Madrid. Centro de Estudios Políticos y Constitucionales, 2015.

36. Sherwin, Emily. "How liberal is liberal equality? A comment on Ronald Dworkin's Tanner Lecture." Legal Theory (1995): 227-250.

37. Shiffrin, Steven. "Liberalism, Radicalism and Legal Scholarship." UCLA Law Review 30 (1983): 1103-1217.

38. Walzer, Michael. Thinking Politically: Essays in Political Theory. New Haven: Yale University Press, 2007.

39. Williams, Bernard. "Dworkin on Community and Critical Interest." California Law Review 77 (1989): 515-520.

\section{LEGAL REFERENCES}

1. Constitutional Court of Colombia, 1994, no. C-133.

2. Constitutional Court of Colombia, 1994, no. C-350.

3. Constitutional Court of Colombia, 1994, no. T-401.

4. Constitutional Court of Colombia, 1996, no. C-045.

5. Constitutional Court of Colombia, 1996, no. T-669.

6. Constitutional Court of Colombia, 1997, no. C-214.

7. Constitutional Court of Colombia, 1997, no. C-239.

8. Constitutional Court of Colombia, 1998, no. C-404.

9. Constitutional Court of Colombia, 2001, no. C-1287.

10. Constitutional Court of Colombia, 2005, no. C-1041.

11. Constitutional Court of Colombia, 2006, no. C-355.

12. Constitutional Court of Colombia, 2011, no. C-817.

13. Constitutional Court of Colombia, 2012, no. C-241.

14. Constitutional Court of Colombia, 2013, no. T-773.

15. Constitutional Court of Colombia, 2014, no. T-314.

16. Constitutional Court of Colombia, 2016, no. SU-214.

17. Constitutional Court of Colombia, 2017, no. C-174.

18. Constitutional Court of Colombia, 2017, no. T-361.

19. Constitutional Court of Colombia, 2018, no. C-009.

20. Constitutional Court of Colombia, 2018, no. SU-023.

21. Constitutional Court of Colombia, 2018, no. T-468. 